\title{
THE DENSITY OF THE EGGS OF CALANUS FINMARCHICUS
}

\author{
By E. A. Salzen \\ Department of Zoology, University of Edinburgh, and Marine Station, Millport
}

(Text-fig. I)

The vertical distribution of plankton organisms and their eggs depends largely on their surface area and density (Eyden, 1923). Gross \& Raymont (1942) observed that the eggs of Calanus finmarchicus had a density (I.045$\mathrm{I} \cdot 049 \mathrm{~g} / \mathrm{cc})$ greater than that of sea water $(\mathrm{I} \cdot 0235-\mathrm{I} \cdot 025 \mathrm{~g} / \mathrm{cc})$, and that they sank at the rate of approximately $2.5 \mathrm{~cm} / \mathrm{min}$ at $13^{\circ} \mathrm{C}$. These workers pointed out that since the embryo takes $24 \mathrm{~h}$ to complete development, the eggs will sink in still water to a depth of $36 \mathrm{~m}$ before hatching and yet the data available, although not extensive, suggests that both eggs and nauplii are found most abundantly nearer the surface than this (Nicholls, I933; Kraefft, I9I0). If these observations are correct, then in addition to density and viscosity, there must be a third factor affecting the distribution of these eggs. Unfortunately, Gross \& Raymont did not consider the possible effect of viscosity in their method for determining density, and they themselves commented on the disturbing degree of variation in some of their results. Their measurements of the rate of sinking of the eggs in sea water also showed considerable variation. It seemed worth while, therefore, to measure the density of these eggs using the density gradient technique of Linderstrøm-Lang (I937), a method which enables the individual and precise measurement of the density of small living objects, independent of their shape, i.e. surface area. This method was being used in work on Psammechinus eggs at the Marine Station, Millport, and, at the suggestion of Dr A. P. Orr, the following measurements were made on the eggs of Calanus finmarchicus.

\section{METHODS}

The principles of the gradient-tube method have been fully described elsewhere (Linderstrøm-Lang \& Lanz, I938; Løvtrup, 1950; Linderstrøm-Lang, Jacobson \& Johansen, I938). The medium used was a thorotrast-distilled water mixture made isotonic with sea water by the addition of $0.092 \mathrm{~g}$ $\mathrm{KCl}+3.46 \mathrm{~g} \mathrm{NaCl}$ per $100 \mathrm{cc}$ of mixture. (Thorotrast, a stabilized colloidal solution of thorium oxide, has a high density, low viscosity, a negligible osmotic pressure, and is relatively transparent. It has been used for gradients in the Carlsberg Laboratory.) An artificial sea-water medium was used because natural sea water was found to cause precipitation of the thorotrast. 
The gradient was about $10 \mathrm{~cm}$ in height and covered linearly a density range of $\mathrm{I} \cdot 048-\mathrm{r} \cdot 098 \mathrm{~g} / \mathrm{cc}$. Thus a difference in height of $\mathrm{I} \mathrm{mm} \mathrm{in} \mathrm{the} \mathrm{gradient}$ corresponded with a density difference of $0.0005 \mathrm{~g} / \mathrm{cc}$. The density standards were small hollow glass beads (of I-2 mm diameter) previously made and standardized against droplets of standard potassium chloride solutions in bromobenzene-kerosene gradients. These standards were accurate to $\pm 0.0005 \mathrm{~g} / \mathrm{cc}$ and the positions of the eggs in the gradient could easily be measured to $0.1 \mathrm{~mm}$ with a cathetometer.

Measurements were made at $22 \pm 0.0 \mathrm{I}^{\circ} \mathrm{C}$ on mixed batches of eggs which had been laid during the night and were approximately $\mathrm{I} 2 \mathrm{~h}$ old at the time of the experiments. Two determinations on separate days were made, 20-30 eggs being used on each occasion. The eggs fell as a group in the gradient, and their rate of fall was measured with reference to one egg chosen at random. The small amount of water introduced with the eggs from a braking pipette remained at the top of the gradient tube. The gradient itself was not affected because of the large amount of medium contained in the upper reservoir of the gradient tube. The positions of all the eggs and the standards were measured at suitable intervals for up to $2 \frac{1}{2} \mathrm{~h}$ after entry into the gradient. The diameters of several mixed batches of eggs were measured, with an ocular micrometer, with an accuracy of $\pm 3 \mu$.

\section{RESULTS}

The results of the two experiments are shown in Table I. Fig. I shows a typical set of measurements of the position of an egg throughout the hour following its entry into the gradient. This suggests that the eggs should have reached their definitive positions (i.e. the position at which egg and medium have the same density) within I h of entry. This is a slow fall and is due to the small size of the eggs, i.e. high surface-area/volume ratio, giving a high viscosity effect. (In the gradient method viscosity may affect the rate of fall of the material but it does not affect its final position in the gradient.) It is clear from Fig. I that the $\frac{1}{2} \mathrm{~h}$ readings are likely to give density values a little too low. The values for $2 \mathrm{~h}$ in Expt. I and $\mathrm{I} \frac{1}{2} \mathrm{~h}$ in Expt. 2 may be of doubtful value because the eggs had become opaque, i.e. cytolysed, and may have changed in density. However, this seems unlikely, because if the egg shell is intact internal changes will not affect the egg density; and indeed the opaque eggs were quite steady in the gradient. The progressive decrease in sample size in the second experiment was due to eggs which burst and sank rapidly to the bottom of the gradient. Control eggs remained unchanged for $2 \mathrm{~h}$ in the thorotrast-saline mixture at room temperature, while others in the artificial sea water showed signs of deterioration.

Thus from Expt. I the density of Calanus eggs at $22^{\circ} \mathrm{C}$ appears to be $\mathrm{I} \cdot 0735 \mathrm{~g} / \mathrm{cc}$ with a standard deviation for the population of $0.0005 \mathrm{~g} / \mathrm{cc}$. The final value in Expt. 2 supports this, although the standard deviation is much 
larger. If all the measurements be included, except those of the first half-hour, then the results for the two experiments are:

Expt. I. Mean density $=\mathrm{I} \cdot 074 \mathrm{~g} / \mathrm{cc}$. Standard deviation $=0.00075$.

Expt. 2. Mean density $=\mathrm{I} \cdot 074 \mathrm{~g} / \mathrm{cc}$. Standard deviation $=0.0018$.

Since the standards were accurate to \pm 0.0005 , then the density of Calanus eggs may be taken as $\mathrm{I} \cdot 074 \mathrm{~g} / \mathrm{cc}$ with a population standard deviation of $0.002 \mathrm{~g} / \mathrm{cc}$.

Table I. Density of Eggs of CALANUS FinMaRChicus as DETERMINED IN THE DeNSity GRADIENT

\begin{tabular}{|c|c|c|c|c|c|}
\hline Expt. & $\begin{array}{l}\text { Time } \\
\text { since } \\
\text { eggs } \\
\text { entered } \\
\text { gradient } \\
\text { (h) }\end{array}$ & $\begin{array}{c}\text { No. } \\
\text { of eggs } \\
\text { measured }\end{array}$ & $\begin{array}{c}\text { Mean } \\
\text { value } \\
\text { of } \\
\text { density } \\
(\mathrm{g} / \mathrm{cc})\end{array}$ & $\begin{array}{l}\text { Standard } \\
\text { deviation }\end{array}$ & $\begin{array}{c}\text { Condition } \\
\text { of } \\
\text { eggs }\end{array}$ \\
\hline I & $\begin{array}{l}\frac{1}{2} \\
1 \\
2\end{array}$ & $\begin{array}{l}22 \\
22 \\
22\end{array}$ & $\begin{array}{l}I \cdot 0725 \\
I \cdot 0735 \\
I \cdot 0745\end{array}$ & $\begin{array}{l}0.00075 \\
0.0005 \\
0.0006\end{array}$ & $\begin{array}{l}\text { Normal } \\
\text { Normal } \\
\text { Opaque }\end{array}$ \\
\hline 2 & $\begin{array}{l}\frac{1}{2} \\
\mathrm{I} \\
\mathrm{I} \frac{1}{2} \\
2 \frac{1}{2}\end{array}$ & $\begin{array}{r}28 \\
\text { I3 } \\
\text { II } \\
8\end{array}$ & $\begin{array}{l}I \cdot 0730 \\
I \cdot 0750 \\
I \cdot 0750 \\
I \cdot 0735\end{array}$ & $\begin{array}{l}0.00025 \\
0.0005 \\
0.002 \\
0.00125\end{array}$ & $\begin{array}{l}\text { Normal } \\
\text { Opaque } \\
\text { Opaque } \\
\text { Opaque }\end{array}$ \\
\hline
\end{tabular}

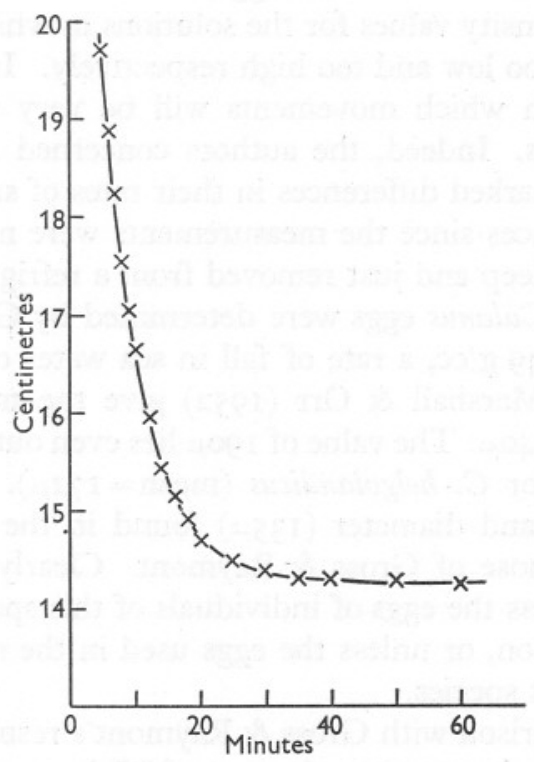

Fig. I. The fall of an egg of Calanus finmarchicus in a thorotrast gradient. The height of the egg above an arbitrary fixed point has been plotted against the corresponding time from the moment of entry of the egg into the gradient. 
The results of the diameter measurements are given in Table II. The eggs were, within the accuracy of the measurements, quite spherical. If all the measurements be taken together, the mean diameter for the population becomes I $35 \mu$ with a standard deviation of $4 \mu$.

\section{TABle II. Diameter of EgGS of CALANUS FINMARCHICUS}

$\begin{array}{cccc}\text { Expt. } & \begin{array}{c}\text { No. of } \\ \text { eggs } \\ \text { measured }\end{array} & \begin{array}{c}\text { Mean } \\ \text { value of } \\ \text { diameter } \\ (\mu)\end{array} & \begin{array}{c}\text { Standard } \\ \text { deviation } \\ (\mu)\end{array} \\ \text { I } & 26 & 140 & 3.0 \\ & 20 & 129 & 3.5 \\ 2 & 25 & 134 & 4.0\end{array}$

\section{Discussion}

Gross \& Raymont (1942) determined the density of Calanus eggs by measuring their rates of movement in gum solutions of increasing density, and found that the rate of fall decreased linearly, the egg and the medium having the same density at zero velocity. This, however, only applies if the effect of viscosity is constant or can be neglected, for the rate of movement will be reduced by the increasing viscosity as well as the increasing density of the gum solutions. If the retardation of movement due to viscosity is considerable, as may well be with such small bodies as Calanus eggs, then the method becomes very insensitive, giving density values for the solutions in which the eggs just sink or just rise that are too low and too high respectively. In fact there will be a range of solutions in which movements will be very slow and subject to extraneous influences. Indeed, the authors concerned report that different specimens showed marked differences in their rates of sinking-perhaps due to extraneous influences since the measurements were made in glass cells or watch-glasses $2 \mathrm{~cm}$ deep and just removed from a refrigerator.

Three values for Calanus eggs were determined by Gross \& Raymont-a density of I.045-I.049 g/cc, a rate of fall in sea water of $2.5 \mathrm{~cm} / \mathrm{min}$, and a diameter of $190 \mu$. Marshall \& Orr (1952) give the mean diameter of $C$. finmarchicus eggs as $140 \mu$. The value of $190 \mu$ lies even outside the range which these authors give for $C$. helgolandicus (mean $=\mathrm{I} 72 \mu$ ). The values for egg density $(\mathrm{I} \cdot 074 \mathrm{~g} / \mathrm{Cc})$ and diameter $(\mathrm{I} 35 \mu)$ found in the present work differ considerably from those of Gross \& Raymont. Clearly both sets of values cannot be right, unless the eggs of individuals of this species differ markedly in size and constitution, or unless the eggs used in the separate experiments were from a different species.

For further comparison with Gross \& Raymont's results it is of interest to calculate, using Stokes's equation, the rate of fall in sea water of an egg with diameter $\mathrm{I} 35 \mu$ and density $\mathrm{I} .074 \mathrm{~g} / \mathrm{cc}$, i.e. with the values determined in the present work. Values for the temperature and salinity of the sea water must 
be assumed in order to obtain values for density and viscosity. If the sea water has a temperature of $15^{\circ} \mathrm{C}$ and a salinity of $35 \%$, then the viscosity will be $12.2 \times 10^{-3}$ c.g.s. units (Sverdrup et al., I942, p. 69) and the density $\mathrm{I} \cdot 026 \mathrm{~g} / \mathrm{cc}$ (Knudsen, I90I; Matthews, I932). Inserting these values in the equation

$$
v=\frac{2}{9} \frac{a^{2} g\left(d_{1}-d_{2}\right)}{\eta},
$$

where $v=$ rate of fall $(\mathrm{cm} / \mathrm{sec})$,

$a=$ radius of egg $(\mathrm{cm})=0.00675 \mathrm{~cm}$,

$g=$ acceleration due to gravity $\left(\right.$ dynes $\left./ \mathrm{cm}^{2}\right)=98 \mathrm{I}$ dynes $/ \mathrm{cm}^{2}$,

$d_{1}=$ density of egg $(\mathrm{g} / \mathrm{cc})=\mathrm{I} \cdot 074 \mathrm{~g} / \mathrm{cc}$,

$d_{2}=$ density of sea water $=\mathrm{r} \cdot 026 \mathrm{~g} / \mathrm{cc}$,

$\eta=$ viscosity of sea water (c.g.s. units) $=12 \cdot 2 \times 10^{-3}$ c.g.s. unit,

we obtain

$$
v=0.0393 \mathrm{~cm} / \mathrm{sec}=2.36 \mathrm{~cm} / \mathrm{min} .
$$

Thus the theoretical rate of fall in sea water is in fair agreement with the experimentally determined value of Gross \& Raymont, and their comments on the vertical distribution of Calanus eggs are still valid. If the previously mentioned reports concerning the abundance of eggs near the surface are accurate, then there must be some factor which materially slows down the rate of sinking of these eggs in the sea. A detailed analysis of their distribution might help in determining the part played by turbulence in this respect.

The results also show that although measurements of the rate of fall of spherical bodies, such as eggs, in sea water can give values for their density, the method is much less sensitive than direct measurements as in the Linderstrøm-Lang gradient method. Furthermore, the possible effect of viscosity must be considered when measuring rates of movement in solutions of different density, and for this reason Gross \& Raymont's work on the nauplii and adults of Calanus awaits confirmation by methods independent of viscosity.

\section{SUMMARY}

The Linderstrøm-Lang density gradient technique has been used to determine the density of the eggs of Calanus finmarchicus. The mean density for the population was $\mathrm{I} \cdot 074 \mathrm{~g} / \mathrm{cc}$ with a standard deviation of $0.002 \mathrm{~g} / \mathrm{cc}$. Measurements of egg diameter gave a mean of $135 \mu$ with a standard deviation of $4 \mu$. This would give a rate of fall in sea water (salinity $35 \%$ and temperature $\mathrm{I} 5^{\circ} \mathrm{C}$ ) of the order of $2.4 \mathrm{~cm} / \mathrm{min}$. 


\section{REFERENCES}

Eyden, D., I923. Specific gravity as a factor in the vertical distribution of plankton. Proc. Camb. Phil. Soc. (biol. Sci.), Vol. I, pp. 49-55.

Gross, F. \& Raymont, J. E. G., I942. The specific gravity of Calanus finmarchicus. Proc. roy. Soc. Edinb., B, Vol. 6I, No. 2I, pp. 288-96.

KNUdsen, M., r9or. Hydrographical Tables. 63 pp. Copenhagen: G. E. C. Gad.

KRAEFFT, F., I9IO. Über das Plankton in Ost- und Nordsee und den Verbindungsgebieten, mit besonderer Berücksichtigung der Copepoden. Wiss. Meeresunters. (Abt. Kiel), N.F., Bd. II, pp. 29-108.

LINDERSTRøM-LANG, K., I937. Dilatometric ultra-micro-estimation of peptidase activity. Nature, Lond., Vol. I39, pp. 713-I4.

LINDERSTRøM-LANG, K., JACOBSON, O. \& JoHANSEN, G., 1938. On the measurement of deuterium content in mixtures of $\mathrm{H}_{2} \mathrm{O}$ and $\mathrm{D}_{2} \mathrm{O}$. C.R. Lab. Carlsberg (Sér. chim.), Vol. 23, pp. 17-26.

LINDERSTRøM-LANG, K. \& LANZ, H., 1938. Studies on enzymatic histochemistry. XXIX. Dilatometric micro-estimation of peptidase activity. C.R. Lab. Carlsberg (Sér. chim.), Vol. 21, pp. 315-38.

LøVTRUP, S., I950. Determination of density of amoebae by means of a starch density gradient. C.R. Lab. Carlsberg (Sér. chim.), Vol. 27, pp. I37-44.

Marshall, S. M. \& ORR, A. P., I952. On the biology of Calanus finmarchicus. VII. Factors affecting the egg production. F. mar. biol. Ass. U.K., Vol. 30, pp. 527-48.

Matthews, D. J., I932. Tables of the Determination of Density of Sea Water under Normal Pressure, Sigma-t. 59 pp. Copenhagen: Conseil Perm. Int. Explor. Mer.

Nicholss, A. G., I933. On the biology of Calanus finmarchicus. III. Vertical distribution and diurnal migration in the Clyde sea area. F. mar. biol. Ass. U.K., Vol. I9, pp. 139-64.

Sverdrup, H. U., Johnson, M. W. \& Fleming, R. H., I942. The Oceans. 1087 pp. New York. 